\title{
Antibodies to streptococcal opacity factor in a selected Indian population
}

\author{
KUNTI PRAKASH and SHIPRA DUTTA \\ WHO Collaborating Centre for Reference and Training in Streptococcal Diseases, Department of Microbiology, Lady \\ Hardinge Medical College, New Delhi, 110001, India
}

\begin{abstract}
Summary. Antibody to at least one type of streptococcal opacity factor (OF) was present in $39.0 \%$ of 235 selected subjects and, in $47.8 \%$ of these, to more than one type. Only $21.6 \%$ of children less than 4 years old had antibody to OF; these were to one type in $62.5 \%$ or to more than one in $37.5 \%$. In the study group as a whole, the commonest antibodies were those to OF from M-serotype 25 followed, in descending order, by serotypes 4, 22, 2, 9, 48, 49, 28, 61 and 75. Patients with rheumatic fever or rheumatic heart disease most often had antibodies to OF from M-types 25, 22, 4 and 9, whereas in patients with acute glomerulonephritis, antibodies to OF from M-types 48,49 and 61 were commonest. The limitations of the OFinhibition test as an epidemiological marker for prevalent M-types of group A streptococci are discussed.
\end{abstract}

\section{Introduction}

The production of opacity factor (OF), a lipoproteinase, by certain serotypes of $\beta$-haemolytic streptococci of Lancefield's group A is well documented. ${ }^{1,2} \mathrm{OF}$ is serologically specific ${ }^{3}$ and corresponds exactly with the M-type of the streptococcus that produces it. ${ }^{4}$ Antibodies to OF persist in human sera for 4-12 years. $^{2}$ Although only 27 of the $71 \mathrm{M}$-serotypes ${ }^{5}$ currently known produce $\mathrm{OF},{ }^{2}$ the consistent production of OF, its type specificity and its close association with $\mathrm{M}$-antigen, and especially the fact that $45-60 \%$ of all isolates of group A streptococci produce $\mathrm{OF}^{6,7}$ suggest that identification of antibody to $O F$ could be used to reflect the prevalence of streptococcal M-types in a population. ${ }^{8,9}$

In the present study, the prevalence of OF antibody in a selected population has been examined, and by extension, exposure to specific OF-positive M-serotypes has been determined.

\section{Materials and methods}

\section{Subjects}

From 1986 to 1989, sera were collected and examined from 235 subjects aged from one to 30 years (mean 15.5 years). All were attending the Kalawati Saran Children's Hospital, the Smt. Sucheta Kriplani

Received 19 June 1989; revised version received 22 March 1990 accepted 31 July 1990.
Hospital, the All India Heart Foundation or the All India Institute of Medical Sciences, New Delhi.

Thirty sera were collected from eight male and 22 female patients, mainly outpatients who were suffering from recurrent sore throat with a positive throat culture for a $\beta$-haemolytic group A streptococcus or had supportive evidence of group A streptococcal infection in the form of an elevated titre of ASO or anti-DNAase B or both. Eighty-five sera were collected from 58 male and 27 female patients with rheumatic fever (RF) or rheumatic heart disease (RHD) diagnosed on the basis of modified Jones' Criteria $;{ }^{10}$ they were receiving 1.2 mega-units of benzathine penicillin every 3 weeks as secondary prophylaxis. Fifty sera were collected from 29 male and 21 female patients with clincially confirmed acute glomerulonephritis ${ }^{11}$ (AGN) with skin or throat culture positive for the group A streptococcus or supporting evidence of group A streptococcal infection in the form of an elevated titre of ASO or anti-DNAase B or both. Control sera were collected from 70 children and adults, matched for age and sex, who lacked bacteriological or serological evidence or recent group A streptococcal infection.

\section{Streptococcal strains}

Twenty-two OF-producing strains of group A streptococci (table I) and a non-producing control strain of Lancefield's group C (Chestle Prague No. 41/ 59) were obtained from (the late) Dr J. Rotta, Director, 
Table I. Antigenic characteristics of the 22 standard OF-positive group A streptococci used in the study

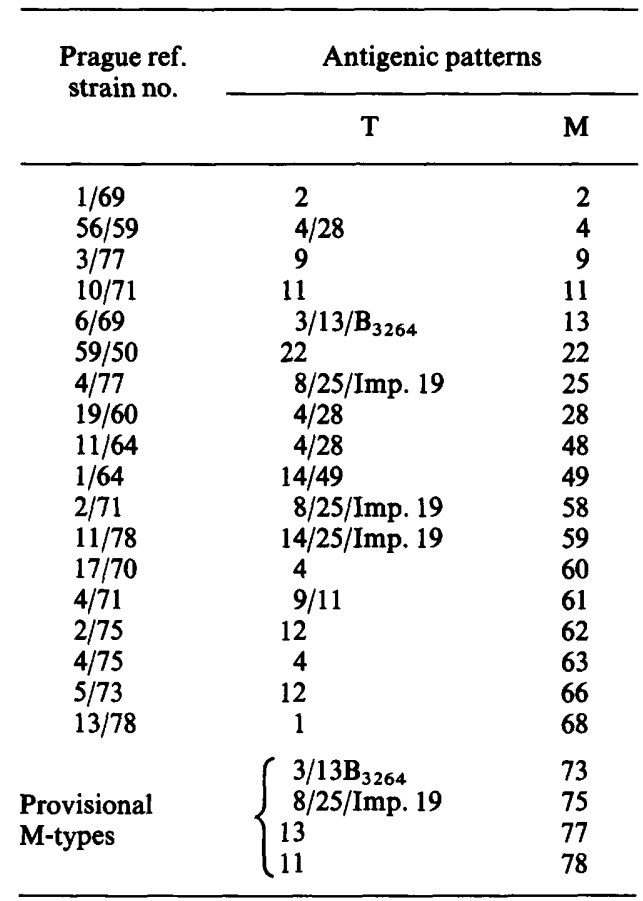

WHO Collaborating Centre for Reference and Research on Streptococci, Institute of Hygiene and Epidemiology, Prague, Czechoslovakia.

\section{Test for $O F$}

All 22 strains were tested for $O F$ production after growth overnight at $30^{\circ} \mathrm{C}$ in $20 \mathrm{ml}$ of Todd-Hewitt Broth (Difco Laboratories, Detroit, Michigan, USA) to which neopeptone $1 \% \mathrm{w} / \mathrm{v}$ had been added. After centrifugation at $3000 \mathrm{rpm}$ for $15 \mathrm{~min}$, each supernate was tested for the serum opacity reaction (SOR) by an agar slide method $^{7}$ with pig serum as substrate. Briefly, pig serum $(1 \mathrm{ml})$ adjusted to $\mathrm{pH} 6.0$ was mixed with $1 \mathrm{ml}$ of molten Noble Agar (Difco) $2 \% \mathrm{w} / \mathrm{v}$ in distilled water at $50^{\circ} \mathrm{C}$ and the mixture was poured evenly over a $5 \times 5-\mathrm{cm}$ glass slide, allowed to solidify, and thereafter dried for $10 \mathrm{~min}$ at $37^{\circ} \mathrm{C}$. Culture supernates were spotted on to the slide with a 2-mm loop and the slides were placed in a moist chamber for overnight incubation at $37^{\circ} \mathrm{C}$.

A positive reaction was indicated by the development of a zone of opacity. Supernates containing OF were preserved at $4^{\circ} \mathrm{C}$ after sodium merthiolate was added to a final concentration of $1: 5000 \mathrm{w}: \mathrm{v}$. These preparations could be used thereafter for up to 4 weeks to detect anti-OF antibodies in human sera. One standard strain of group $\mathrm{C}$ was used as a negative control throughout the study.

\section{Determination of anti-OF antibodies in human sera}

To $1 \mathrm{ml}$ of pig serum, $0.3 \mathrm{ml}$ of OF preparation and
$1 \mathrm{ml}$ of molten Noble Agar $2 \%$ at $50^{\circ} \mathrm{C}$ were added. The mixture was poured on to a $5 \times 5$-cm glass slide. One such slide was prepared with each of the $22 \mathrm{OF}$ preparations. The slides were dried for $10 \mathrm{~min}$ at $37^{\circ} \mathrm{C}$ before each of the 165 test and 70 control sera was spotted with a $2 \mathrm{~mm}$ loop onto the surface of slides prepared with each OF. Sixteen sera could be tested conveniently on one slide. The slides were incubated in a moist chamber overnight at $37^{\circ} \mathrm{C}$. A clear area in the opaque background was taken to indicate anti-OF antibody.

\section{Results}

Of 235 sera tested, $92(39.0 \%)$ contained antibodies either to a single OF type $(52.2 \%)$ or to multiple OF types $(47.8 \%)$. Of 37 samples from children aged $1-4$ years, including three with RF/RHD, seven with AGN, one with pharyngitis and 26 normal controls, 8 $(21.6 \%)$ contained antibodies to OF. None of the sera from patients with RF/RHD or pharyngitis contained $O F$ antibodies whereas four of seven sera from patients with AGN did, in one case against a single OF type and in three against multiple OF types. In 26 normal control children, aged 1-4 years, four had OF antibodies against single $\mathbf{M}$-serotypes (table II).

Serum from $49.0 \%$ of subjects more than 4 years old contained antibody to single or multiple OF types. Sera from patients with pharyngitis were most likely to contain antibody (53.3\%) followed by sera from patients with RF/RHD (44.7\%), with AGN $(38.0 \%)$ and from normal subjects $(27.0 \%)$. Antibodies to more than one OF type were more likely in patients with RF/RHD (55.3\%), than in patients with pharyngitis $(43.7 \%)$ or AGN (42.0\%) or in healthy subjects $(42.0 \%)$. More sera from patients with RF/RHD contained antibody to two or more OF types $(55.3 \%)$ than to a single serotype $(44.7 \%)$. These antibodies to OF in patients with RF/RHD sera were to OF from M-types 25 (16 cases), 22 (13), 4 (10) and 9 (9); the serum of five of these patients each contained antibodies to four different M-serotypes (table III).

In patients with $A G N$ the most prevalent antibodies were those to $\mathrm{OF}$ from M-types 48 (8 cases), 59 (5) and 61 (4). In this group, most of the sera (57.9\%) contained antibody to $\mathrm{OF}$ from a single serotype, most commonly M-type 48 or 49. Eight serum samples had antibody to $\mathrm{OF}$ from more than one M-serotype. Antibodies to OF from M-serotypes most often seen in RF/RHD25,22 and 4-were also present in sera from patients with AGN, though less often. However, antibodies to OF from M-type 9, seen in nine patients with RF/ RHD, were not found in patients with AGN. Similarly, antibodies to OF from M-type 49 or 61 (frequent in patients with AGN) were not found in patients with RF/RHD (table III).

Sera from patients with pharyngitis most often contained antibodies to OF from M-type 2 (8 cases). However, antibodies to OF from types 25, 22, 4 and 9 


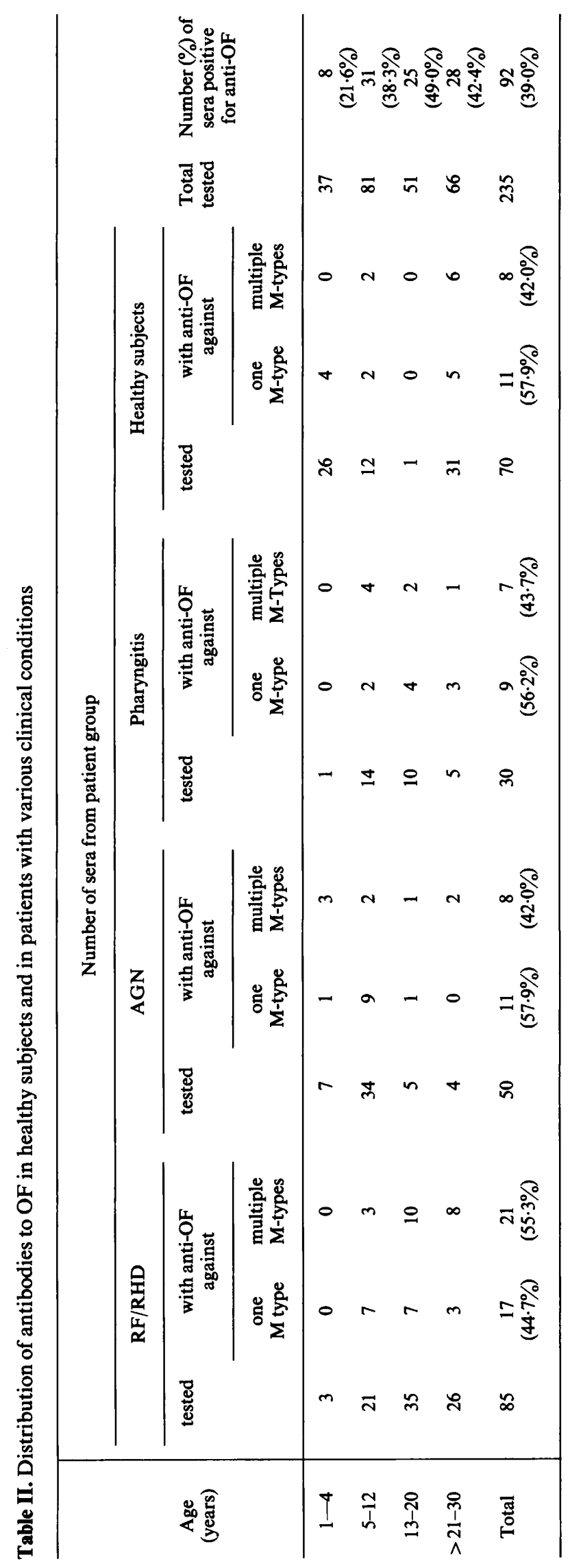


Table III. Distribution of antibodies to OF-positive $\mathbf{M}$ serotypes in patients with RF/RHD or AGN

\begin{tabular}{|c|c|c|c|}
\hline \multirow{2}{*}{$\begin{array}{c}\text { Clinical } \\
\text { conditions } \\
\text { (number of sera } \\
\text { examined) }\end{array}$} & \multirow{2}{*}{$\begin{array}{l}\text { Number of sera } \\
\text { showing OF } \\
\text { antibodies }\end{array}$} & \multicolumn{2}{|c|}{ Anti-OF antibodies (number of sera) against } \\
\hline & & $\begin{array}{l}\text { single } \mathbf{M} \\
\text { serotype }\end{array}$ & two or more than two $\mathrm{M}$ serotypes \\
\hline $\begin{array}{c}\text { RF/RHD } \\
\quad(85)\end{array}$ & $\begin{array}{c}38 \\
(44 \cdot 7 \%)\end{array}$ & $\begin{array}{c}4^{*}(2) \\
9^{*}(3) \\
22^{*}(3) \\
25^{*}(5) \\
58(1) \\
59(1) \\
73(1) \\
75(1) \\
(17 ; 44 \cdot 7 \%)\end{array}$ & $\begin{array}{cc}9,25(1) & 4,11,25(2) \\
22,25(2) & 4,22,25(2) \\
22,58(1) & 4,66,73(1) \\
25,78(1) & 9,28,58(1) \\
28,58(1) & 11,66,73(1) \\
68,75(1) & 59,73,77(1) \\
73,75(1) & 4,9,22,25(3) \\
9,22,28,48(1) \\
11,22,28,48(1) \\
(21 ; 55 \cdot 3 \%)\end{array}$ \\
\hline $\begin{array}{c}\text { AGN } \\
(50)\end{array}$ & $\begin{array}{c}19 \\
(38.0 \%)\end{array}$ & $\begin{array}{c}4(1) \\
22(1) \\
48^{*}(4) \\
49^{*}(5) \\
\\
(11 ; 57 \cdot 9 \%)\end{array}$ & $\begin{array}{c}4,25(1) \\
22,25(2) \\
28,77(1) \\
48,61^{*}(2) \\
4,48,61(1) \\
28,48,61(1) \\
\left(8 ; 42 \cdot 0^{\circ}\right)\end{array}$ \\
\hline
\end{tabular}

* Common OF-positive M serotypes.

(often present in the serum of patients with RF/RHD) were present also in the sera of patients with pharyngitis (table IV). In normal subjects too, antibodies to $\mathrm{OF}$ from $\mathrm{M}$-serotypes 25,4 and 49 were frequent. The serum of healthy subjects more often contained antibody to $\mathrm{OF}$ from a single M-serotype (57.9\%) than from multiple types $(42.0 \%)$. None of the sera tested contained antibodies to OF from M-types 60 or 62 .

Within the population studied, antibodies to OF from M-type 25 were commonest (25), followed by types 4 (19), 22 (18), 2 (11), 9 and 48 (10 each), 49 (8) and 28, 61, 75 (three each) (table V).

Table IV. Distribution of antibodies to OF-positive $M$ serotypes in patients with pharyngitis and in healthy subjects

\begin{tabular}{|c|c|c|c|}
\hline \multirow{2}{*}{$\begin{array}{c}\text { Clinical } \\
\text { conditions } \\
\text { (number of } \\
\text { sera examined) }\end{array}$} & \multirow{2}{*}{$\begin{array}{c}\text { Number of } \\
\text { sera showing } \\
\text { OF antibodies }\end{array}$} & \multicolumn{2}{|c|}{$\begin{array}{c}\text { Anti-OF antibodies (number of sera) } \\
\text { against }\end{array}$} \\
\hline & & $\begin{array}{l}\text { single } \mathrm{M} \\
\text { serotype }\end{array}$ & $\begin{array}{l}\text { two or more than } \\
\text { two } M \text { serotypes }\end{array}$ \\
\hline $\begin{array}{l}\text { Pharyngitis } \\
(30)\end{array}$ & $\begin{array}{c}16 \\
(53 \cdot 3 \%)\end{array}$ & $\begin{array}{c}2^{*}(5) \\
22(1) \\
25(1) \\
66(1) \\
75(1) \\
(9 ; 56 \cdot 2 \%)\end{array}$ & $\begin{array}{c}2,75(3) \\
4,9(1) \\
11,61(1) \\
4,22,25(1) \\
59,66,68(1) \\
(7 ; 43 \cdot 7 \%)\end{array}$ \\
\hline $\begin{array}{l}\text { Healthy subjects } \\
\qquad(70)\end{array}$ & $\begin{array}{c}19 \\
(27 \cdot 0 \%)\end{array}$ & $\begin{array}{c}2(2) \\
25(2) \\
49(2) \\
59(1) \\
61(1) \\
66(1) \\
68(1) \\
77(1) \\
(11 ; 57.9 \%)\end{array}$ & $\begin{array}{c}2,4(1) 4,59,63(1) \\
4,25(2) 11,13,49,68(1) \\
25,59(1) \\
28,58(1) \\
58,61(1) \\
\\
(8 ; 42 \cdot 0 \%)\end{array}$ \\
\hline
\end{tabular}

* Common OF-positive M-serotypes. 
Table V. Prevalence of antibodies to OF-positive M serotypes in the population

\begin{tabular}{cccccc}
\hline & \multicolumn{5}{c}{ Number $(\%)$ of sera showing antibodies to OF from patients/controls } \\
\cline { 2 - 6 } $\begin{array}{c}\text { OF-positive } \\
\text { M serotypes }\end{array}$ & $\begin{array}{c}\text { RF/RHD } \\
(\mathrm{n}=85)\end{array}$ & $\begin{array}{c}\text { AGN } \\
(50)\end{array}$ & $\begin{array}{c}\text { pharyngitis } \\
(30)\end{array}$ & $\begin{array}{c}\text { healthy subjects } \\
(70)\end{array}$ & $\begin{array}{c}\text { All } \\
(235)\end{array}$ \\
\hline 25 & $16(18 \cdot 8)$ & 2 & 2 & 5 & $25(10 \cdot 6)$ \\
4 & $10(11 \cdot 8)$ & 3 & 2 & 4 & $19(8 \cdot 0)$ \\
22 & $13(15 \cdot 3)$ & 3 & 2 & 0 & $18(7 \cdot 7)$ \\
2 & 0 & 0 & $8(26 \cdot 6)$ & 3 & $11(4 \cdot 7)$ \\
9 & $9(10 \cdot 6)$ & 0 & 1 & 0 & $10(4 \cdot 2)$ \\
48 & 2 & $8(16 \cdot 0)$ & 0 & 0 & $10(4 \cdot 2)$ \\
49 & 0 & $5(10 \cdot 0)$ & 0 & 3 & $8(3 \cdot 4)$ \\
28 & 4 & 2 & 0 & 1 & $7(3 \cdot 0)$ \\
61 & 0 & $4(8 \cdot 0)$ & 1 & 2 & $7(3 \cdot 0)$ \\
75 & 3 & 0 & 4 & 0 & $7(3 \cdot 0)$ \\
\hline
\end{tabular}

\section{Discussion}

It has been suggested that inhibition of OF by specific antibody might allow evaluation of a population's previous exposure to specific OF-positive $\mathrm{M}$ serotypes of group A streptococci. ${ }^{2}$ However, although antibodies to $\mathrm{OF}$ in general parallel $\mathrm{M}$-antibodies, so that a complex bactericidal test can be replaced by simpler enzyme neutralisation, the epidemiological value of studies based on detection of antibody to OF is limited as only $27 \mathrm{M}$-serotypes of group $\mathrm{A}$ streptococci are currently recognised as OF producers. $^{2}$ However, in practice $45-60 \%$ of all clinical isolates of group A streptococci produce $\mathrm{OF}^{6,7}$ so that, by studying antibodies to OF in human sera, it is possible to judge indirectly but usefully the prevalence of infection by different serotypes of streptococci in different populations. The infrequent isolation ${ }^{12}$ and poor M-typability of strains ${ }^{13,14}$ at the time of the development of streptococcal sequelae are the two major constraints in projecting with certainty the responsible and prevalent streptococcal serotypes in a population.

In the present study antibodies to OF were present in $39.0 \%$ of the sera tested. Of these, $47.8 \%$ contained antibodies to more than one OF type, suggesting repeated streptococcal infection but with different $O F$ types. Only $21.6 \%$ of children aged up to 4 years had antibodies to OF. In three patients, all with AGN, antibody to more than one OF type was present. The other children, both those who had streptococcal infection and healthy controls, had antibody to a single OF type. It has been reported that the incidence of RF varies with age, the peak both for first attacks and recurrences being between 5 and 15 years. ${ }^{12}$ However, in developing countries, onset at between 3 and 5 years of age is not unusual, ${ }^{15-17}$ and serological response to streptococcal infection in children less than 5 years old is generally poor, irrespective of the $\mathrm{M}$-serotype involved. ${ }^{18}$ Repeated streptococcal infections are common in patients who develop streptococcal sequelae, especially RF/RHD. ${ }^{19}$ In the present study most patients with RF/RHD (55.3\%) had antibodies to more than one OF type. Reviewing outbreaks of RF, Stollerman ${ }^{14}$ found that a limited number of serotypes were involved (M-types 5, 18, 19, 24) and that none of these produced OF. However, $M-4^{20}$ and $M-11^{14,21}$ OF-positive serotypes have been reported to be associated with RF. The definition of rheumatogenic strains remains unclear.

Antibodies to OF of M-serotypes 25, 22, 4 and 9 were commoner in RF/RHD cases but it is doubtful if such types cause reactivation of the disease: antibodies to OF of M-serotypes 25 and 4 were also quite common in normal subjects.

The prevalence of higher M-types 22 (49 and above) in patients with AGN has been reported; the finding in the present study of antibodies to OF of M-serotypes $48,49,61$ in patients with AGN agrees with this. Serotype M- 49 has been implicated in AGN in widely differing locations ${ }^{23}$ but is more often associated with pyoderma than with pharyngitis.

Antibodies to OF have been reported to persist for as long as M-type specific antibodies. ${ }^{2,24}$ Study of their type-specificity indirectly but usefully indicates the serotypes of streptococci prevalent in different populations.

The study was performed with financial support from the Indian Council of Medical Research, New Delhi, India.

\section{References}

1. Gooder H. Association of a serum opacity reaction with serological type in Streptococcus pyogenes. J Gen Microbiol $1961 ; 25$ : 347-352.

2. Johnson DR, Kaplan EL. Microtechnique for serum opacity factor characterization of group A streptococci adaptable to the use of human sera. J Clin Microbiol 1988; 26 : 20252030.

3. Top FH, Wannamaker $\mathbf{L W}$. The serum opacity reaction of Streptococcus pyogenes: the demonstration of multiple strain-specific lipoproteinase antigens. J Exp Med 1968; 127: 1013-1034. 
4. Widdowson JP, Maxted WR, Grant DL. The production of opacity in serum by group A streptococci and its relationship with the presence of M-antigen. J Gen Microbiol 1970; 61: $343-352$

5. Rotta J. Streptococcal diseases. Acta Pathol Microbiol Immunol Scand 1988; 96 Suppl 3: 3-7.

6. Top FH, Wannamaker LW. The serum opacity reaction of Streptococcus pyogenes: frequency of production of streptococcal lipoproteinase by strains of different serological types and the relationship to M-protein production. $J$ Hyg (Camb) 1968; 66: 49-58.

7. Maxted WR, Widdowson JP, Fraser CAM, Ball LC, Bassett DCJ. The use of the serum opacity reaction in the typing of group-A streptococci. J Med Microbiol 1973; 6: 83-90.

8. Maxted WR, Widdowson JP, Fraser CAM. Antibody to streptococcal opacity factor in human sera. J Hyg (Camb) $1973 ; 71: 35-42$.

9. Iontova IM, Totalian AA. Lipoproteinase of group A streptococci and the antibodies in human sera. Zentralbl Bakteriol Mikrobiol Hyg [A] 1 Orig 1975; 233: 452-463.

10. Jones TD. Jones criteria (revised) for guidance in the diagnosis of rheumatic fever. Circulation 1984; 69: 204A-208A.

11. Basu PK. Clinical study of acute glomerulonephritis. Antiseptic 1970; 67: 333 .

12. Taranta A, Markowitz M (eds) Rheumatic fever, 2nd edn. UK, Kluwer Academic Publishers, England 1989: 13, 19, 44

13. Fox EN. M proteins of group A streptococci. Bacteriol Rev $1974 ; 38: 57-86$.

14. Stollerman GH. Global changes in group A streptococcal diseases and strategies for their prevention. Year Book Medical Publishers. 1982: 373.
15. Kuttner AG, Krumwiede E. Observations on effect of streptococcal upper respiratory infections on rheumatic children: 3-year study. J Clin Invest 1941; 20: 273-287.

16. Mabilangan LM, Chua EL. Rheumatic fever and rheumatic heart disease in the Phillippines. In: Lue HC, Kawakita S, Chu SH, Okuni M (eds) Year of the rheumatic child. Taiwan. 1983: 37-44.

17. Majeed AM, Yousof AM, Shaltont A, Khuffash FA. Acute rheumatic fever below the age of five years: a prospective study of the clinical profile. Ann Trop Paediatr 1984; 4: 37 40

18. Flores AE, Johnson DR, Kaplan EL, Wannamaker LW. Factors influencing antibody responses to streptococcal $M$ proteins in humans. J Infect Dis $1983 ; 147: 1-15$.

19. Unny SK, Middlebrooks BL. Streptococcal rheumatic carditis. Microbiol Rev 1983; 47: 97-120.

20. Rammelkamp CH, Denny FW, Wannamaker LW. Studies on the epidemiology of rheumatic fever in the armed services. In: Thomas L (ed) Rheumatic fever. Minneapolis, University of Minnesota Press. 1952: 72-89.

21. Bisno AL, Pearce IA, Wall HP, Moody MD, Stollerman GH Contrasting epidemiology of acute rheumatic fever and acute glomerulonephritis. Nature of the antecedent streptococcal infection. $N$ Engl J Med 1970; 283: 561-565.

22. Wannamaker LW. Differences between streptococcal infections of the throat and of the skin. $N$ Engl J Med 1970;282: 23-31, 78-85.

23. Stollerman GH. Nephritogenic and rheumatogenic group A streptococci. J Infect Dis 1969; 120: 258-263.

24. Lancefield RC. Persistence of type-specific antibodies in man following infection with group A streptococci. J Exp Med 1959; 110: 271-292. 